Article

\title{
Dyeing the Springtime: The Art and Poetry of Fleeting Textile Colors in Medieval and Early Modern South Asia
}

\section{Sylvia Houghteling}

History of Art, Bryn Mawr College, Bryn Mawr, PA 19010-2899, USA; shoughteli@brynmawr.edu

Received: 2 October 2020; Accepted: 15 November 2020; Published: 24 November 2020

\begin{abstract}
This paper explores the metaphorical and material significance of short-lived fabric dyes in medieval and early modern South Asian art, literature, and religious practice. It explores dyers' manuals, paintings, textiles, and popular and devotional poetry to demonstrate how the existence of ephemeral dyes opened up possibilities for mutability that cannot be found within more stable, mineral pigments, set down on paper in painting. While the relationship between the image and the word in South Asian art is most often mutually enhancing, the relationship between words and color, and particularly between poetry and dye color, operates on a much more slippery basis. In the visual and literary arts of South Asia, dye colors offered textile artists and poets alike a palette of vibrant hues and a way to capture shifts in emotions and modes of devotion that retained a sense of impermanence. More broadly, these fragile, fleeting dye materials reaffirm the importance of tracing the local and regional histories even of objects, like textiles, that circulated globally.
\end{abstract}

Keywords: color; textiles; dyes; festivals; poetry; painting; South Asia

\section{Introduction}

When the medieval poet, Amīr Khusrau (1253-1325) beseeched his Sufi teacher, Nizāmuddīn Auliyā, for spiritual instruction, he did so in the language of dyes and color: "Colorful [raingīle], come color me in your own hue./You are my lord, Beloved of God./My veil [shawl] and my lover's turban, color them both with spring./You are my lord, Beloved of God./As the price you demand for the pigment,/ accept the payment of my flowering youth" (Losensky and Sharma 2011, p. 105). ${ }^{1}$ The metaphor travels across three levels: the devotee begs his Sufi master, or $p \bar{\imath} r$, to initiate him, to envelop him, to teach him, and thus to "color me in your own hue". At the same time, he is also asking that both his veil or shawl (chadariyā) and his turban (pagrīy $\bar{a})$ be dyed with the color of "spring" (basanti raing). As recompense, or mortgage, he offers the springtime of his life, "my flowering youth" (joban). There is instability in the poem's central metaphor of color and dyeing: raing is at once a pigment, a belief, springtime itself, and can be bought only with one's youthful bloom. The poet also introduces an ambiguous temporality. While Amīr Khusrau's request to be initiated into Sufi learning would seem to be a lifetime conversion, the metaphor of the Sufi master dyeing his shawl and turban makes the imagery tangible, earthly, and thus finite. The references to basantī rang conjure Basant Pañchamī, the South Asian springtime festival when celebrants wear yellow clothing and bedeck themselves in mustard flowers and marigolds. Amīr Khusrau is said to have first introduced the celebration of Basant Pañchamī to Nizāmuddīn Auliyā, a tradition to that continues at the saint's dargāh to this day

1 The connected themes of spring and dyeing occur more than once in Amīr Khusrau's poetry. In another poem, he begs of Nizāmuddīn Auliyā: "this spring, dye my veil" (Losensky and Sharma 2011, p. 106). 
(Qureshi 1993, p. 115). If a later, nineteenth-century ethnographic account is any indication, basantī rang came to refer to an actual dye, likely a bright yellow color made from a short-lived flower or fruit-based dye. Yet the word rang itself eludes a single translation because it can be both a dye and a color, meaning that basantī rang also readily suggests the more open-ended, impressionistic idea of the color of spring, as Losensky and Sharma have rendered it. In this poem, Amīr Khusrau employs dyes and colors as metaphors that could move easily between the tangible and the evocatively unstable, between the enduring and the ephemeral. He was not the last to utilize the language of passing colors in his poetry. In dyers' manuals, paintings, textiles, and later popular and devotional poetry, short-lived dyes opened up possibilities for mutability that cannot be found within more stable, mineral pigments, set down on paper in painting.

The relationship between the image and the word in South Asian art is most often mutually enhancing, with the literary and visual arts contributing to a fuller mental picture. The relationship between words and color, and particularly between poetry and dye color, however, operates on a much more slippery basis. Metaphors of dye colors offered the textual arts a way to capture shifts in emotions and modes of devotion that retained a sense of impermanence. References to ephemeral dyes in literature span regional sites and range across the medieval period to the nineteenth century, but the small group of dye materials that seem to have been evoked remained largely consistent, and even persisted with the advent of chemical dyes. Moreover, while the emotional and ethical valence of impermanent dyes varied within devotional, popular, and courtly textual traditions, the language of these dyes and colors, much of which derives from flowers and the natural world, consistently tracked more closely onto passing seasonal temperaments than eternal states of being. Transient dye colors were not just a poetic conceit, but had physical correlates in the form of actual dyes with which poets seem to have been familiar. This interdisciplinary study examines metaphors of dye materials both to understand their role in poetry, but also to learn what literature can tell us about the historical usage of dyes that have largely disappeared. By reintegrating the material circumstances and visual experience of dye colors with their appearance in textual form, this study aims to recapture both the vibrancy and temporal possibilities that these lost colors brought to the visual and textual arts of South Asia. More broadly, the significance that fragile dye materials once held reaffirms the importance of tracing the local and regional histories even of objects, like textiles, that circulated globally.

The very particular temporality that short-lived dyes inhabited can perhaps explain their prevalence in both metaphorical and material form. In recent years, interdisciplinary scholarship has come to focus on the more ephemeral, sensory aspects of religious and aesthetic experience in medieval and early modern South Asia. Daud Ali, Emma Flatt, and Dipti Khera have drawn attention to the bodily regimes and spaces of pleasure that were central to courtly culture, exploring the political and religious importance of such practices as perfuming the body, the use of fragrant sandalwood pastes, and gathering festively in sites of physical enjoyment (Ali 2004, 2011; Flatt 2019; Khera 2020). Renewed interest in South Asian theories of rasa, which can be translated as aesthetic experience, feeling, or taste has demonstrated the importance of sensory experience and emotions to classical Indian aesthetics (Pollock 2016, p. 42). As part of a rising concern with historical ecology, recent work focuses on representations of water in early Indian art and has worked to recover the history of long-gone landscapes and gardens (Jain-Neubauer 2016; Ray 2017). While dyes and cloth-dyeing could be stable instances of indelible pigments, they also existed alongside perfumes, waterways, and theatrical performances as exemplars of both material and metaphorical transience.

There are unique historical challenges inherent in any attempt to recover sensory experiences, passing moods, and once-verdant, original environments. In the case of dye materials, fabrics are fragile things, particularly in warm climates. Most historical textiles have disappeared through decomposition or, in the case of precious cloths, from being burned for their metal threads. Even if the fabric itself has survived, the dyes studied here would often only last for a year, or would fade in the sun. Records of these dyes are also elusive. Dyers did not often write down their recipes and whole categories of dye materials have likely been lost. For this reason, when dyes do appear in texts, it is more often in 
the creations of authors and poets who were not always faithful to the material properties of dyes, but rather employed the colors to serve their literary aims or the meter of their verse.

Yet texts are still vital for understanding the meanings of colors and the precise, historical significance of the materials and processes used to produce these hues. Phyllis Granoff has shown that the appearance of colors and the effects of cloth dyes were not excluded from sophisticated poetic or esoteric philosophical realms: in medieval Buddhist philosophy, the existence of cloth dyed with multiple colors inspired a revised theory of reality (Granoff 2004, 2020). Recently, critical accounts of color have historicized the unstable, "nomadic" meanings of different hues across time and place, pointing to the potential from the colonial period into the twentieth century for both violence and agency in indigo-blue, "Indian yellow", and sparkling gold (Bailkin 2005; Brown 2020; Eaton 2012, 2013; Lally 2019). While these accounts often focus on the more stable mineral and vegetable pigments of painting, they demonstrate the cultural and political significance of both the materiality and visual appearance of color. For this reason, while ethnographic accounts from more recent periods can help in tracing the history of dyes in medieval and early modern India, they must also be approached with caution given the changing identities and meanings of pigments over time.

With the importance of Indian textiles as global commodities, it can seem counterintuitive that dyes could, at times, be associated in the poetic imaginary with fluidity and ephemerality. South Asian cloth, which from an early date was traded westward to Africa, the Middle East and Europe, and eastward to China, Japan, and Southeast Asia, was renowned for its color-fast dyes (Fee 2020; Gittinger 1982; Phipps 2013; Riello 2010). Indigo and red colors from the madder, chay, and āl dyes found on the earliest Indian trade textiles sent to Egypt were stable, long-lasting and resisted fading (Barnes 1997, p. 58). Even today, centuries later, indigo textiles in particular have retained their rich, jewel-like blue tones. The red dyes, which only adhered to the cotton textiles after the application of a metallic mordant, were, like the indigo, chemically bonded into the fibers of the cotton. The colors received high praise: a French observer noted in the eighteenth century that the dyes on traded Indian chintz cloth would "last as long as the cloth itself" (Huet 1719, p. 137).

The rich red and blue colors of South Asian textiles were not the only visual effects of value. Tang-era Chinese texts praised Indian textiles that resembled the "sunrise clouds of morning", and Indian musicians clothed in "dawn-flushed cotton" (Dale 2009, p. 84). While these accounts are indicative of the light texture of the cotton cloths, they also suggest a spray of color that is delicate and that quickly dissipates. Even the deep indigo dye is said to have first been discovered by way of a seasonal accident. People living near forests, where indigo plants grew wild, may have realized that they had blue-dyed feet after they walked through the soil where wet indigo leaves were decomposing after the monsoon (Sarkar 2015, p. 388). Indigo leaves that have been picked fresh must soon begin fermenting in clay pots, a reason offered for the traditional overlapping identities of indigo dyers and potters (Sarkar 2015, p. 390). Today, indigo is still used as a temporary hair dye.

The materials for South Asia's dye colors also varied in terms of their duration. Vibrant and shorter lived, many more local dye colors existed along seasonal, regional pathways. In the era before the advent of chemical dyes in the nineteenth century, dye colors overlapped with culinary spices, medicinal herbs, and body pigments and included turmeric, henna, kumkum, and safflower (Carthamus tinctorius), the last of which was a frequently-discussed dye color in medieval texts. Safflower is a thistle-like plant that is native to southern Asia and it has been used as a dye material since antiquity (Hofenk de Graaff 2004, p. 160). Its petals produce a range of bright yellow, orange, pink, and red colors. Though safflower was known to be a quickly-fading colorant, dyers and consumers were willing to forgo longevity of color in order to access the brilliant shades that safflower produced. In Japan, the name for safflower is beni, and despite its short-lived nature, the dye material has been treasured and regulated by sumptuary laws for centuries (Figure 1) (Jackson 2020). In Japanese poetry, the red hue produced by repeatedly dyeing silk or cotton cloth in safflower is the color of seduction and fickle love. It is associated with youthful coquetry and courtesans and is contrasted with the enduring gray colors worn by a faithful wife (Bethe 1992, p. 134; Bethe 1984, p. 60). 


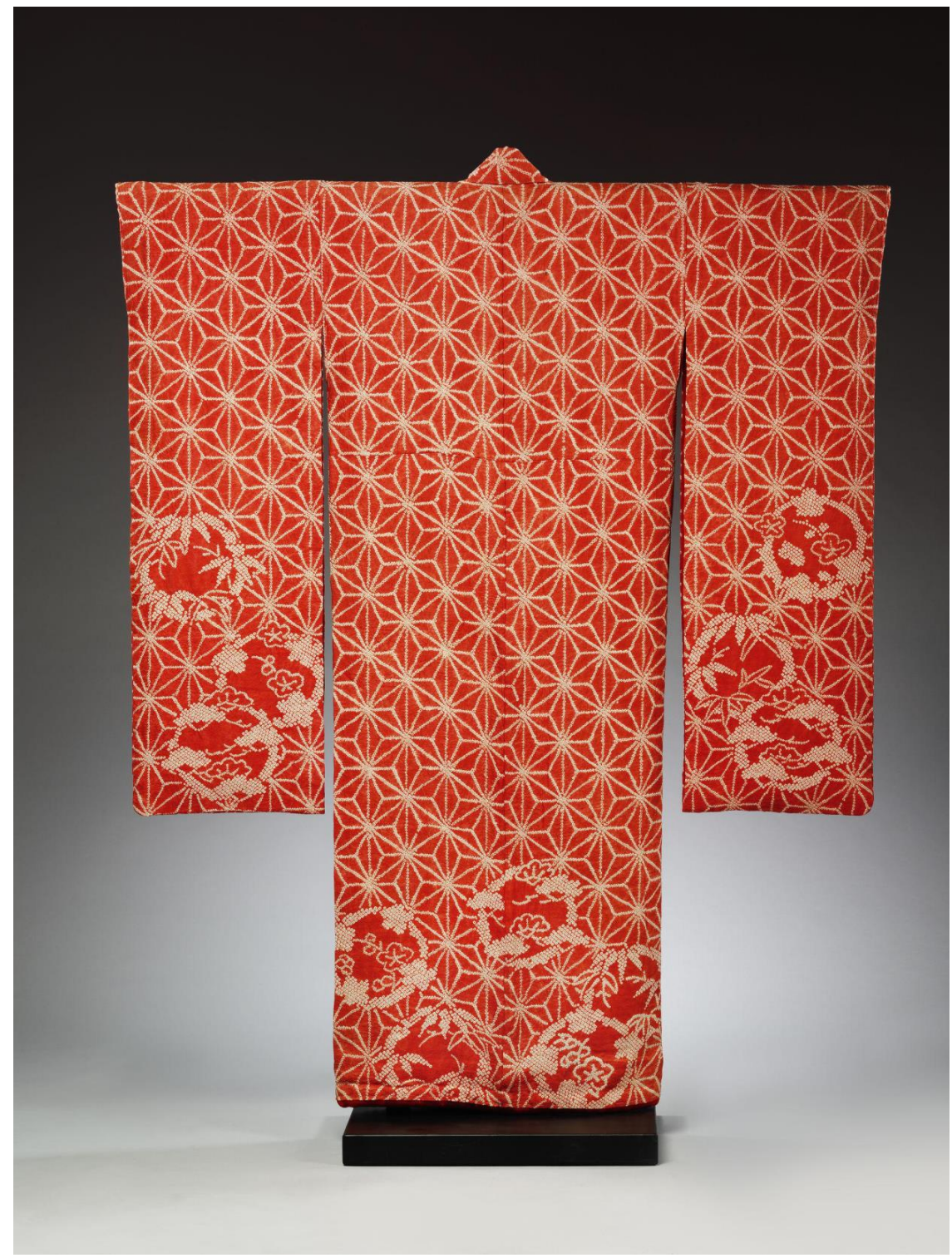

Figure 1. Kimono dyed with safflower; figured satin silk with tie-dyed decoration; Japan, 1800-1840. FE.32-1982. (C) Victoria and Albert Museum, London.

In medieval and early modern South Asia, kusumbha or kasumal-dyed cloths (the names given for textiles dyed with safflower) were valued as religious offerings and as the material for precious garments. Although saffron has become a religiously-potent color in the past century, it was the vibrant, and fleeting yellow, orange, red, and pink colors produced by safflower that more frequently appeared in earlier manuals on gift-giving and accounts of religious festivities (Jha 2014). As Sadan Jha notes, nineteenth accounts describe a special class of dyers in northern India, known as kusumbhawalas, who worked solely with safflower dyes to color turbans and other cloths (Jha 2014, p. 206). More generally, safflower dye was included in the palette of the rangrez, the dyers who worked with all colors except for blue, which was the exclusive, and often lower-status, dominion of indigo dyers (Sarkar 2015, pp. 394-95). Over the last century, kasumal, the name for the hue produced by safflower, has at times shed its association with the safflower dye material and has come to mean a red-pink color. As more recent, ethnographic accounts attest, kasumal is a favored color for the wedding garments of brides and bridegrooms (Murphy and Crill 1991, p. 25; Bhandari 2004, p. 181). Despite its prevalence as a colorant and its recurrence in poetry, safflower has been overshadowed in histories of textiles by more enduring dyes, in part because safflower's once-vibrant effect on textiles has long-since faded. 
Fruits and flowers traditionally served as the physical manifestation of very short periods of time- of a one-night blossoming of love, or of a passing romantic affair that quickly sours. When Kṛnna and Rādhā are depicted in their flower-covered bower, it is understood that the flowers will soon wilt, like Rādhā's good spirits after Kṛṣna's departure. Colors on cloth represent a more intermediate span of time-less-stable dye colors will last in dark, dry spaces, but when the cloth is exposed to dripping water or sunlight, the color may run, or fade away. In Hindī, these dyes are called "kachch" $\bar{a}$ " dyes, a word that can mean something unripe or unready in the context of fruit. In Urdu, they are called "be-qarārī" dyes—qarārī means fixed and stable, while its opposite, "be-qarār $\bar{\imath}$ " means restless or unsettled (Platts 1884, pp. 203, 789). In English, short-lived dyes are known as "fugitive" dyes, which, as their name implies, suggests something that flees from the cloth. A quickly-fading dye is one that leaves too soon, that is restless, unreliable, unready. It is something that cannot be trusted. In the medieval and early modern periods, however, there was a vibrancy, desirability, but also an unpredictability, to these dyes' behavior that seems to have heightened their appeal as a color and their efficacy as a metaphor.

\section{The Lessons of Short-Lived Dyes}

In medieval Sanskrit and Prakrit texts, we learn that the value of dye colors was not necessarily tied to methods of production or length of duration. For instance, the Dānakānda of the Krtyakalpataru, a text on medieval Brahmanical gift-giving, specifically prescribed that to commemorate certain lunar days, cloths dyed in mahârajana should be given (Brick 2009, p. 216). While, as David Brick notes, "mahārajana" could mean saffron, the dyestuff suggested by mahārajana could also be translated as turmeric, safflower, or a cloth flecked with gold (Apte [1957] 1959, p. 1252). Moti Chandra cites a medieval Prakrit lexicon that mentions various types of fine textiles colored in safflower dye, suggesting their high value (Chandra 1973, p. 125).

In other instances, the fleeting nature of a dye color could be used as a metaphor for the inconstancy and unreliability of lovers. In the eleventh-century text of the Śrngiarramañjarī Kathā, written at the court of King Bhoja of Dhārā in central India, unstable dyes served as a metaphor for the capriciousness and disappointments of relations with male lovers. In this frame narrative, the king's favorite courtesan, Śrngāramañjarī, is educated in the ways of cheating, dim-witted, and profligate men through a series of thirteen stories told by her mother. A recent analysis of this text has focused on the mechanical wonders that King Bhoja describes in the beginning of the narrative (Ali 2016). Yet there is also a more grounded, material dimension to the text: the mother figure introduces each of the first four stories as a rāga whose name refers to a different dye substance. The first $r \bar{a} g a$ is named for a very color-fast dye: the nì $\bar{r} r \bar{g} g a$ (or indigo rāga) is the story of a courtesan who successfully divested a lover of his wealth, but kept him attached to her. It concludes with the lesson: "Thus O daughter, the secret teachings of harlotry yielded good results after the nature of nìlìraga was known. As a cloth dyed in indigo does not fade even when washed by different things like soda, a person of nîlìrāga does not give up his deep attachment even when ruined in a hundred ways" (Munshi 1959, p. 13).

By contrast, the color of mañjisthā, or Indian madder dye, was stable but could fade. For this reason, the lesson of the mañjisthārāga is of a gradual dwindling of attachment: "as a cloth dyed in the mañjisthā does not completely lose its color but fades away as you wash it, persons of mañjisthārāga become gradually detached when offended. Therefore such persons should not be troubled" (Munshi 1959, p. 14). The most violent type of man is likened to the kusumbha, or safflower dye. A courtesan starts up a relationship with a scholar who has accrued wealth. She gradually takes his money and when he realizes that his name has been ruined and his stature diminished, he decides to leave. The courtesan's mother asks him to give her daughter the garment that he is wearing as a token of remembrance. When the courtesan approaches to receive the parting gift, the scholar cuts off her nose and ears. The lesson is vivid: "As a cloth dyed in kusumbha is not fit for heat and washing, persons of kusumbharāga soon become estranged and bring about evil. The wealth of such people therefore should be taken away without giving offence to them" (Munshi 1959, p. 15). The story recognizes the 
instability of kusumbha and its sensitivity to sunlight. Just as the courtesan should tread cautiously with a volatile, violence-prone lover, one should carefully launder and dry a textile dyed with kusumbha.

\section{The Unfixed in Dye Recipes}

The Śrngāramañjarì Kathā is rare for the specificity with which it references dye materials, and it is also more valuable because of the relative absence of other texts on dyes, such as manuals or recipe books. Historians of European dye traditions attribute the scarcity of written dye manuals to the ways that knowledge was passed down orally within guilds or family dye workshops and also to the difficulty of describing tacit knowledge in texts (Nieto-Galan 2010, pp. 321-22). These were circumstances that, for the most part, can also be found in South Asia. Dyers worldwide were working with a set of materials and practices that were reliant upon unsaid conditions: the quality of water or the selection of suitable materials. An exception to this lack of manuals can be found in a set of late-seventeenth- or early-eighteenth-century dyers' recipes that exist in a compilation of medical and artisanal knowledge entitled Khulāṣat al-Mujarrabāt ("Quintessence of Prescriptions") (Naqvi 1980; Khulāsat al-Mujarrabāt 1766). Other chapters in the volume address treatments for horses, ailments of the ear, recipes for perfumes, and instructions for marbling paper (Ethé 1903, pp. 1280-81). The dyers' recipes are written in Persian, likely for a north Indian audience, and the volume contains the date of 1766, although the original text may have been written earlier (Naqvi 1980, p. 59). The recipes include measurements and hands-on information, suggesting that they were created for those who might actually use the recipes or at least for people who were close to the making process. Another indication of the more practical nature of the recipes is that the materials to be dyed were not fine fibers like silk: the recipes simply call for cloth. As Naqvi points out, the materials needed for the recipes were ordinary objects: something to pound the ingredients; a cloth to serve as a sieve; a large pot for boiling (Naqvi 1980, p. 60). The dye materials too were largely available, as they included fruits and spices that were used in cooking, such as pomegranate rinds and turmeric. In this way, the dyers' recipes also resembled the book's other recipes for medicines and perfumes. The recipes outline simple steps to produce bright colors, suggesting that even a lay person might be able to dye cloth using these instructions.

Yet the text does more than just provide material context: the lists of dye colors conjure some of the most brilliant and quickly-fading hues achieved by early modern dyers. Many of the names for the dye colors are drawn from fruits and flowers-mung beans and pomegranate blooms-natural materials whose freshness fades even more quickly than the brilliant pinks and greens of the natural dyer's palette. In the lyrical names for its recipes, the book manages to preserve the strikingly brilliant colors of early modern cloth. Since fabrics themselves have faded, it is only through texts like the dyers' recipes that we can reconstruct the vibrant coloristic effects that early modern dyers achieved.

The recipes make a clear distinction between short-lived and long-lasting dyes. For some colors, the chapter in the Khulāsat al-Mujarrabāt lists both the more fugitive and the more fixed version of a color with the differences emerging from the dye materials used. The recipe for gul-i anār, or a color like the pomegranate flower, is one such example (Figure 2). The recipe contains just three ingredients: turmeric, safflower (indicated by the Persian "shahāb-i khāsa" in this recipe book), and the juice of the sour lemon. It is an approximate recipe, which, like culinary instructions, leaves much up to taste. H.K. Naqvi, who first published and analyzed parts of this text, translates the recipe as follows: "pound the turmeric with water, using a piece of cloth. Strain it. Dye the stuff [fabric], dry it in shade till it gets damp. Add sour lemon in the shahāb-i khāsa (in considerable quantity), dip the damp material in the solution then again dry it in shade" (Naqvi 1980, p. 61; Khulāṣat al-Mujarrabāt 1766, fol. 125 a). A number of features are worth noting here: first, this recipe does not include any mordants, the name given to metallic substances that help some dyes to bind with the cloth fibers. As a result, the requirements for this dye recipe are minimal and the results are very rapid. After dyeing the fabric in turmeric, the cloth is laid out to dry "in the shade" until it is not dry, but merely damp. It is then dyed again in a mixture of sour lemon and a "considerable quantity" of safflower. The recipe, however, 
permits the exact quantity of sour lemons to be decided by the dyer: while pomegranate flowers have a sharp, orange-pink tone, the dyer could choose just how biting to make the hue. Finally, the cloth dries in the shade a second time; one would never dry a safflower-dyed textile in the sun, as it would already begin to fade.

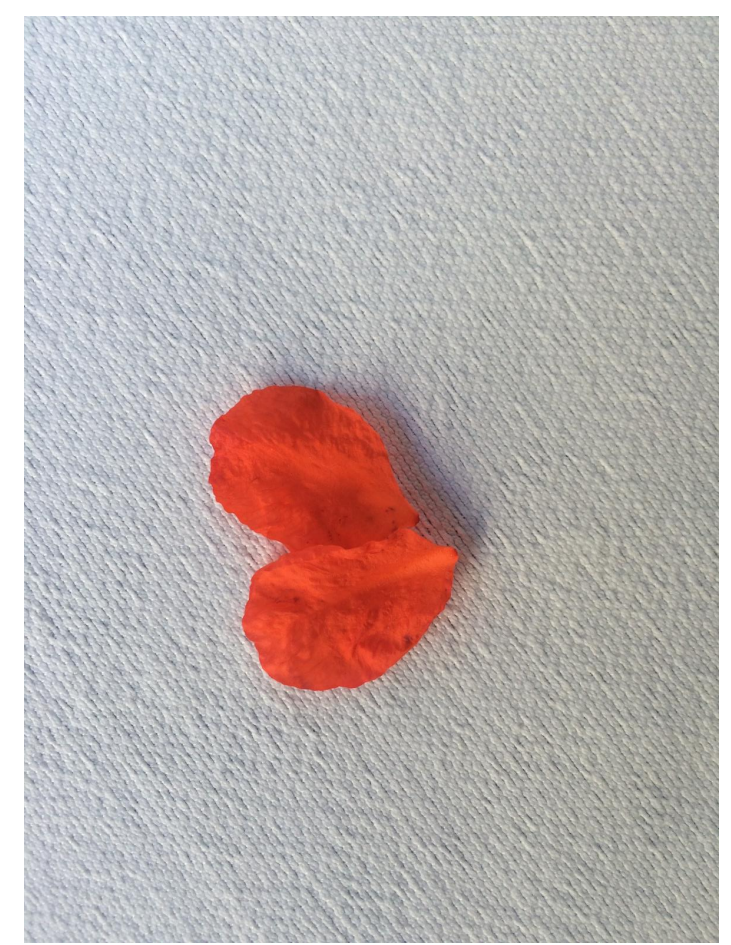

Figure 2. Petals of the Gul-i Anār (Pomegranate Flower). Photograph: Sylvia Houghteling.

The facing page of the text provides the dyer with a recipe for a pink that would last much longer-it is described as "gulābi qarār $\bar{\imath}$ "—which literally means a pink that is fixed, and not restless. The first step requires a precise amount of alum, a very common mordant for dyes. The recipe instructs the dyer to "dip the material in alum water", made from two dams of alum, and then "... dry it. Boil the bark of the kachnār in water, clean the liquid, dye the material, then dry it" (Naqvi 1980, p. 61; Khulāșat al-Mujarrabāt 1766, fol. 125 b). While the flowers of the kachnār tree (Bauhinia variegata) were used in ayurvedic medicine and in cooking, similar to how safflower could also be used in cosmetics or food colors, the kachnār tree bark prescribed here represents a distinctive material from the safflower. The bark of the kachnār was never used for eating, but solely for dyeing and leather tanning. It had to be boiled first to release its color and it was preceded by a metallic mordant. While components of the recipe for $g u l-i$ anār could be digested by the body, the recipe for the fixed pink dye was exclusively a means of coloring cloth.

Another recipe is for a soft yellow, gul-i tura'i, the color of the five-lobed flower of the tura' $\bar{\imath}$, or ridge gourd. Growing at the end of this long, green zucchini-like vegetable, the yellow bloom is delicate and short-lived. The recipe calls for turmeric (using the Persian word, zard chobeh) that has been soaked in water overnight, after which the skin is removed and the turmeric is mashed as it is mixed with water and then strained (Naqvi 1980, p. 68). The dyer then combines the liquid with "soap water" (lit. $\bar{a} b s \underline{a} b \bar{u} n)$, dyes the cloth, and then dries it (Khulāșat al-Mujarrabāt 1766, fol. 120 a). The cloth is then washed with pure water to remove the smell of the soap, and dipped in alum. Although this color may have been more permanent, since the "soap water" likely refers to a basic compound that helped the dye bind to the cloth (in later centuries, "soap water" would contain tin), the instructions to wash out the scent of the soap are a reminder of the immediacy with which these textiles were consumed. The smell did not have time to fade away; it had to be rinsed. By the same measure, these instructions also suggest that many of the dyed textiles were not washed to rid them of their smells, so that even if 
the turmeric in the gul-i tura' $\bar{\imath}$ cloth had had its smell somewhat neutralized, the safflower scent on other cloths remained.

The recipe most relevant to springtime festivals is for the color of the champa flower, the light-yellow flower often likened to and adorning the body of the divine figure of Rādhā. To make this color, the recipe instructs the dyer to boil "peeled tūn" (Cedrela toona), strain the liquid, and dye the material. In the recipe, even less dyestuff is required if one is coloring turbans, or dastār (Naqvi 1980, p. 68; Khulāṣat al-Mujarrabāt 1766, fol. 117 a). The tūn dye is either derived from the flowers of the plant or from its seeds. The instructions to have it "peeled" suggests that the seed has been used and the skin removed. Later accounts all noted the fleeting nature of this dye, which was at times combined with safflower and turmeric. The dyer Sir Thomas Wardle recorded that the yellow color that the tūn dye produces was known as "basant $\bar{\imath}^{\prime}$, the color of spring (Wardle 1886, p. 151).

The dyes that the Khulāsat al-Mujarrabāt prescribes vary between the long-lasting and the ephemeral. Given the propensity of all dyes to fade over time, the colors achieved by the recipes can be recovered through historical reconstruction of the dye recipes or through the imagery that the color names conjure in the mind's eye. Because textiles are three dimensional objects with a back and a front, it is sometimes even possible to encounter the brightest evidence of dye colors simply by turning over a piece of cloth to see the reverse. There is scientific evidence, moreover, for the widespread use of fleeting dyes in the most luxurious textiles made for the Safavid and Mughal courts in the early modern period. Recent dye analysis conducted at the Metropolitan Museum of Art on a collection of Persian and Indian silk velvet textiles from the sixteenth and seventeenth centuries found extensive use of safflower and turmeric. The chemical markers of safflower appeared on nearly all of the pink and orange threads used in the lush velvet pile of Safavid and Mughal velvets (Shibayama et al. 2015). For dyeing threads yellow, the same study found that turmeric had been used to color the majority of yellow threads in Indian velvets (Figure 3). This study of the most precious imperial cloths expands upon the information in the Khulāsat al-Mujarrabāt. It suggests that dyeing with short-lived materials was not a rare practice or confined to lower-priced goods: instead, the finest textiles from across western and southern Asia were made with fragile dyes whose colors have now faded.

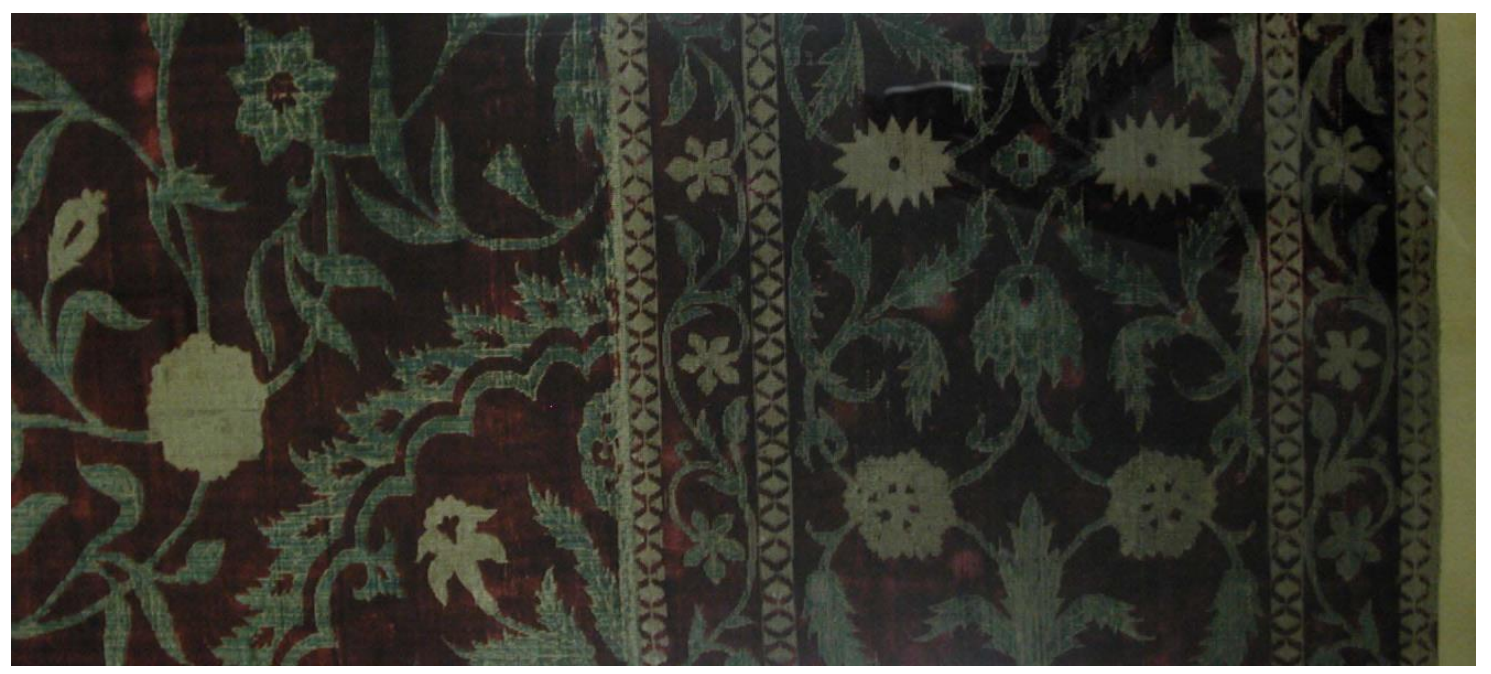

Figure 3. Detail of a hanging with a medallion carpet design, yellow colors dyed with both safflower and turmeric; silk, cut velvet, attributed to India, ca. 1628-58. The Metropolitan Museum of Art, Bequest of George Blumenthal, 1941 (41.190.256).

\section{Running Dyes of the Monsoon}

While medieval literature assigned the short-lived safflower dye to unreliable scoundrels, and fugitive dyes were known to be "restless" by the artisans who used them, the concept of mobile, flowing color also emerged as an expression of the seasonality of festivals and of intense emotional devotion in 
the early modern period. In northern India, and particularly in Rajasthan, both the quickly-fading dye materials and the textiles that they colored were integral to the celebrations that marked the arrival of springtime and the summer monsoon. In the climate of northern India, where temperate weather passes quickly and gives way to longer stretches of hot and dry weather, the dyes' ephemerality also corresponded with the fleeting temporality of the seasons.

During the monsoon season in Rajasthan and central India, men and women alike donned tie-dyed textiles, known as chunnari and lahariy $\bar{a}$, that were made using dyes whose color would weaken in the rain. There is historical evidence from ca. 1600-1900 for the use of chunnari and lahariya textiles at the Rajput courts of Jodhpur, Alwar, Udaipur, Kotā, and Amber-Jaipur, and for chunnarī (also known as bandhān $\bar{\imath}$ ) in Gujarat (Murphy and Crill 1991, pp. 67-71). While the modern-day meanings of textile names can confuse past references, a chunnari can mean a shawl, but it can also suggest a specific tie-dyed textile made by tightly tying up portions of the cloth before dyeing to produce patterns with small dots (Murphy and Crill 1991, pp. 63-67) (Figure 4). The word lahariyā means "wavy" and derives from lahar, or wave, and the textile is made through an intricate tie-and-dye process (Cohen 2015, p. 43). The dyer folds and rolls the original white cotton cloth and ties it tightly in order to protect the undyed parts from the dye bath, and then exposes each of those sections in succession to create a colored pattern, starting with blue, then yellow, and finally red (Graham 2009) (Figure 5). While the separations between the colors are precise, the lines of the pattern undulate, evoking the waves of the cloth's name. When the cloth has been tied into a turban, the lines jostle and shift, the colors rippling over each other and interrupting any sense of orderliness (Figure 6). Worn as a shawl, the cloth folds with the movement of the body. In this sense, the lahariya cloth is both patterned with a wave-like design, and when put into use, it creates wavy forms.

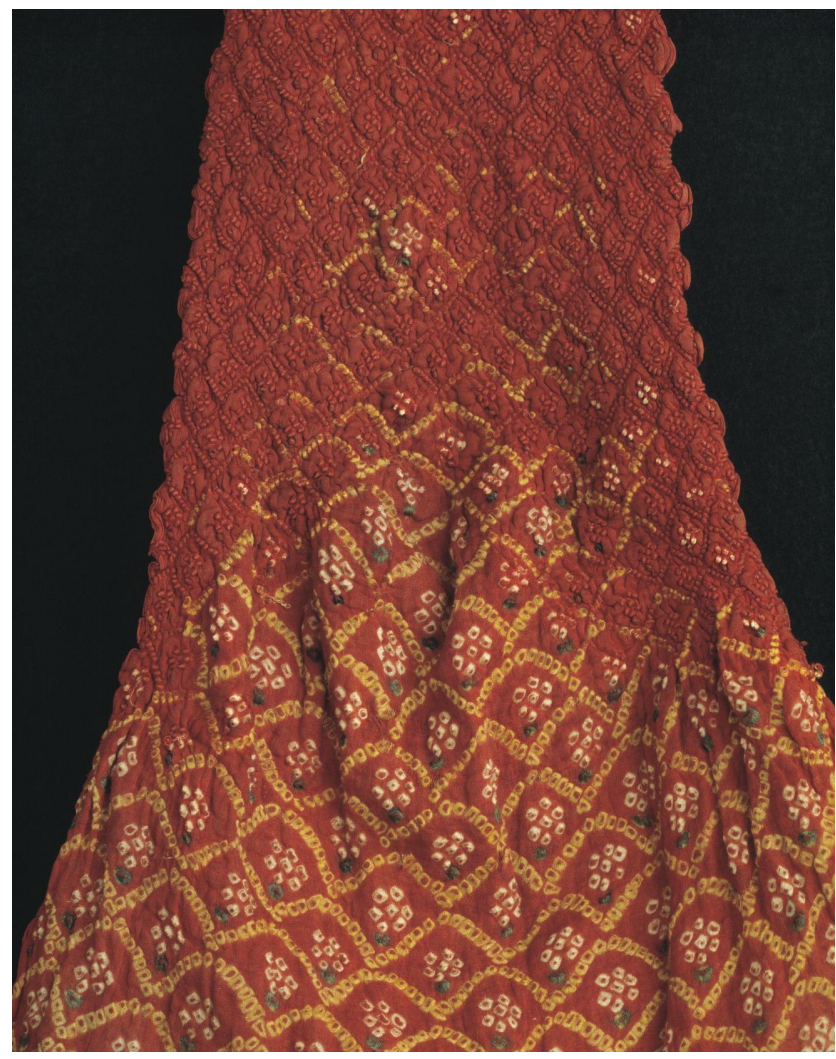

Figure 4. Turban cloth, tie-dyed cotton (chunnarī), Kotā, c. 1860, 7885(IS). (C) Victoria and Albert Museum, London. 


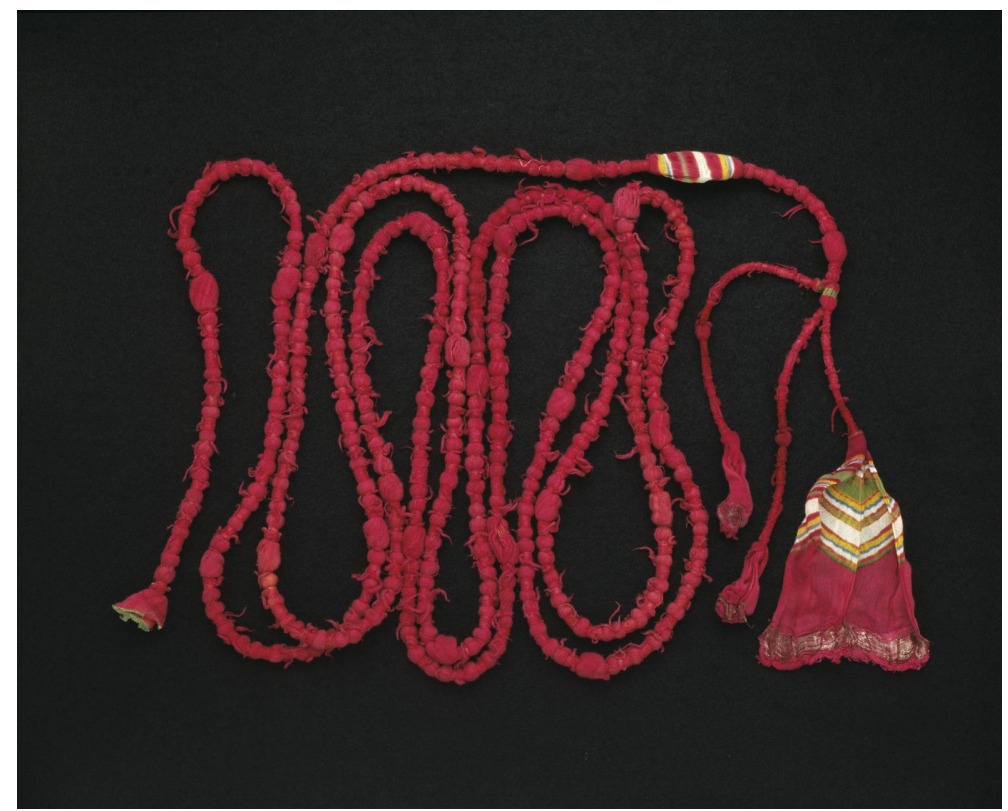

Figure 5. Sample of tie-dyed cloth, tie-dyed cotton, wrap-resist (lahariyā), Jaipur, c. 1950s. Given by Mrs. M. Hamill, IS.63-1959. (C) Victoria and Albert Museum, London.

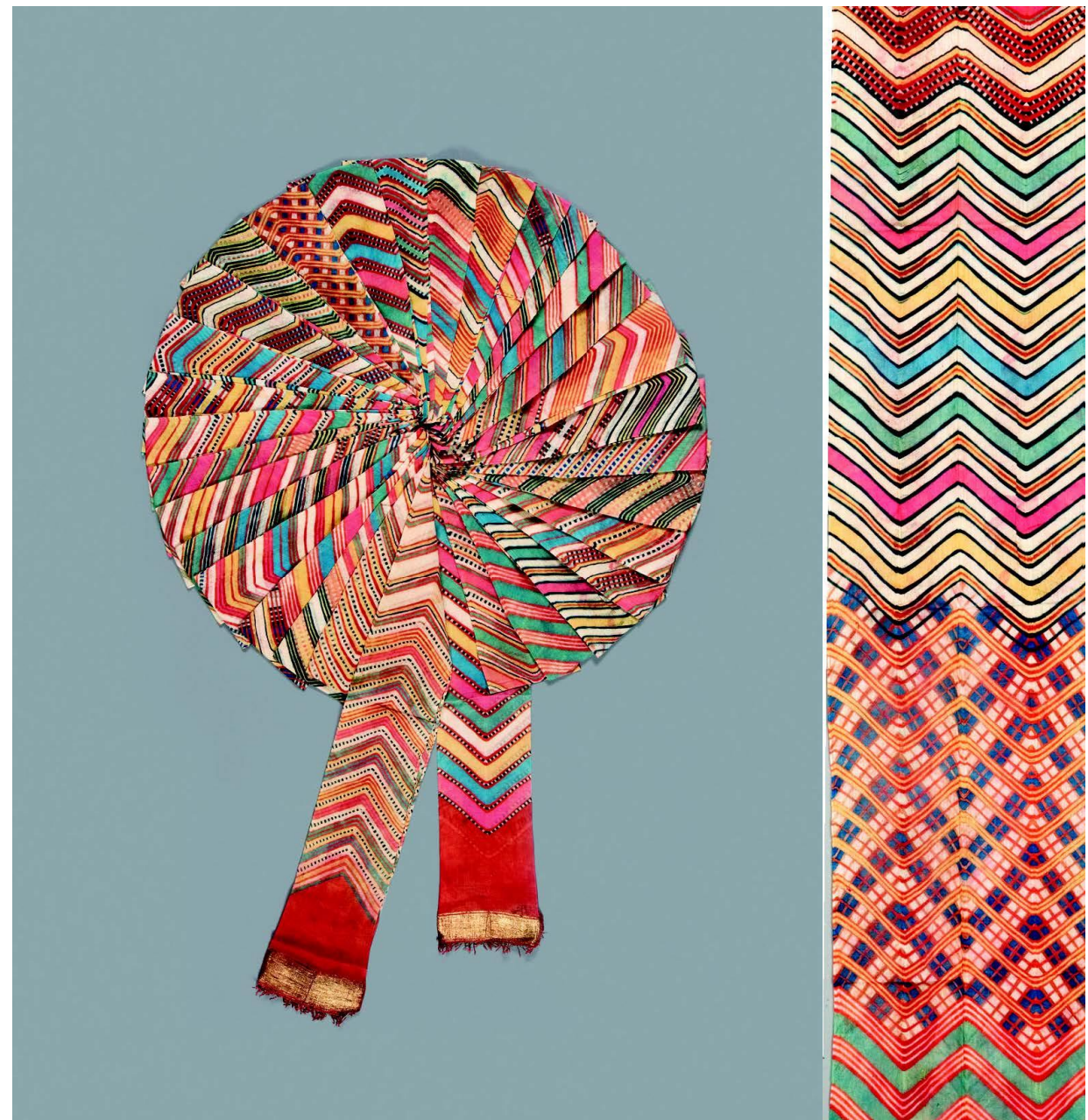

Figure 6. Tie-Dyed Lahariyā turban cloth, Tie-dyed cotton. India (Rajasthan), c. 1840s-1870s. Cora Ginsburg: Costume, Textiles, Needlework. New York: Cora Ginsburg Gallery, 2009-2010, p. 22. Courtesy of Michael Fredericks. 
The safflower dyes used to color these textiles add further mutability. As Vernoica Murphy and Rosemary Crill note, well into the nineteenth century, there remained in Rajasthan a distinction between

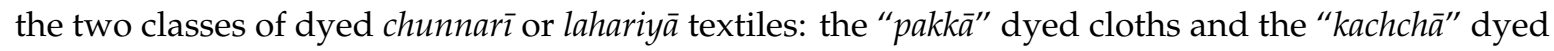
cloths (Murphy and Crill 1991, pp. 72-73). The terminology for this binary emerged from a distinction between foods: $p a k k \bar{a}$ food is the higher status and more ritually pure food and it refers to something stable and cooked. A thing that is kachchā can refer to something raw or unripe, but it can also be polluted and unstable (Marriott 1968, pp. 143-44). The duality can be found in the language of weights and measures: the official weights and measures are the $p a k k \bar{a}$ version; the unofficial, the kachch $\bar{a}$. Architectural structures, land-holdings, and water wells are described variously as pakkā and kachchā.

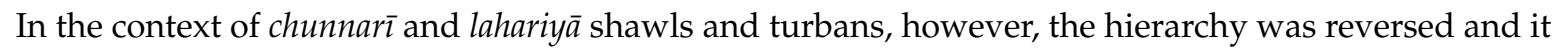
was those made with kachcha dyes that held the higher value. The pakka garments were dyed with the very stable, but duller red āl dye (Morinda cordifolia) and with indigo. Widows and people in mourning wore the pakkā garments (Murphy and Crill 1991, pp. 72-73). The cloths colored with kachchā dyes were made from the finer muslin base fabric and were then dyed in indigo and turmeric for the blue, green, and yellow colors, and then dip-dyed in safflower eight to ten times to achieve the deepest red. As prescribed in the recipe book above, the dyers of these cloths would only dry the colors in the shade. A nineteenth-century account from Kotā suggests that the colors on the cloths would last for one year, provided the fabric was kept dry (Murphy and Crill 1991, p. 197).

When these kachcha turbans and shawls were worn in the rain, however, as they were in Rajasthan to celebrate the monsoon festival of Śrāvan Tìj, the less permanent dyes became wet, relaxing the sharpness of the pattern's lines, and blurring the distinctions between colors. After the season had passed, the fabric was taken to the dyer to be refreshed with new colors (Graham 2009, p. 65). The waving patterns on the cloth, coupled with its blending colors, enhanced lahariy $\bar{a}$ 's association with the watery landscape of the monsoon.

These associations between cloth and season were significant within a genre of seventeenth-century popular poetry that placed textiles into contextual couplets. As Chandramani Singh writes, the poems served a mnemonic function for the laymen who memorized them. The Kapada Kutūhal, one of these seventeenth-century poems from Mewar in present-day Rajasthan, evokes the close, dripping feeling of wearing the lahariya $\bar{a}$ turban in the rain. It describes a lover who "has carefully tied his lahariya turban $[p \bar{a} g]$. A lady as lovely as Śrāvan Tìj (the festival of rains) is almost clinging to his neck" (Singh 1991, p. 182). The lady's body, whose beauty has the feeling of the rain, is wrapped around the neck of her lover. We can imagine the water dripping off the turban and rippling over their entwined arms. For the layman, this couplet combines the name, the use, and the proper season of the textile. The reference to rain and water may also have been significant, as the mutable nature of the turban's dyes was a liability that a wearer should remember in order to protect the cloth in transit.

By contrast, in devotional poetry, the capacity of a dye to spread served as a metaphor for the ideal, all-encompassing, embodied experience of approaching the divine. As Richard David Williams has shown, the devotional Rādhāvallabhī poets of Vṛindāvan used dyeing imagery to suggest the immersive nature of their love for Kṛ̣na and Rādhā. In their poetry, the word ranga is used for dyes and color, but also "enjoyment, excitement, beauty and a state or condition". Williams writes that the poets drew upon this word's dual material and intangible meanings and "often thought of rainga as a liquid dye, into which the divine couple (or even the act of sounding out their names) dips the devotees" (Williams 2018, p. 79).

This liquid dye was also emitted by the divinities into the environment. In one devotional poem that takes place in the monsoon, the rain-soaked garment of Rādhā becomes the subject of the poetry. The shawl that Rādhā wears is described in the poem as a red "chunnarī". As Williams notes, the color red suffuses not only the imagery of the poem, but its very language as variations on the color recur throughout the verses: "Besides the red (suranga) shawl, the river Sarasvati (sarasutī) is red; the simile of lightning is passionate, but also red (anurāga). The red cunnari [chunnarī] is most particularly associated with weddings so, by association, the redness of the vision is infused with the ideal of 
marriage. The multiple meanings of anurāga—red, attachment, passion—sets up the permeability and contagious quality of the color that is also the emotion of the moment" (Williams 2018, p. 88). As the goddess steps into the Sarasvati River, the chunnari releases its red color into the water, and both the color and the emotions of desire and devotion assigned to the shawl run into the river. Williams writes that, "this is one example of the larger metaphor in Rādhāvallabhī literature of color dye, and the transfer of raing as a result of the rain ... the poem as a whole seems to describe the process of catching the color off something else, raing pakarna" (Williams 2018, p. 88). While scene in the poem amplifies how fugitive dye colors were, it allows for a form of color that, like love, and passion, is at once strongly present, and yet quickly dispersing. This metaphor of dyes operates differently than metaphors of flowers, which are fragile, easily crushed, and wilting. The dye has potency and strength. However, it can also pass away, or be passed on as running color, the fever of devotion flowing through to the next supplicant.

This eighteenth-century poem uses the word, chunnarī, to refer to the garment that Rādhā wears. While chunnari could refer to a generic shawl, the description of the dyes flowing out of the cloth suggests that the poet likely intended the word to evoke the dyed cloths worn in the monsoon. A late nineteenth-century account of textile production notes that chunnarī were made in Vrindāvan, the center of Rādhāvallabhī devotion, and that the chunnari cloths were distinctive for their tie-dyed patterns of small dots. The author, T.N. Mukharji, writes that the coloring used was primarily āl, the long-lasting, pakkā dye for the coarser textiles, that yielded a "dull crimson" hue (Mukharji 1883, p. 18). It seems unimaginable that Rādhā would have worn the dull pakkā chunnarī, but would have worn instead the finer, kachcha garment, dyed in such imagined, ephemeral colors that they would drain from the garment when it was submerged in water.

\section{The Springtime of Short-Lived Dyes}

If drenched clothing and dripping dyes pervade the language of the monsoon, it is the much more explosive eruptions of color that characterize the springtime, and particularly the festival of Holi. The colored powders used in contemporary celebrations of Holi are synthetic and are produced in a rainbow of hues. In earlier times, the colors derived from natural plant and mineral-based pigments that were often mixed with water and sprayed, bathing white clothing in a spectrum of reds, pinks, and yellows. One of the most characteristic colors of Holi is the bright-red kumkum powder, made from turmeric mixed with slaked lime. Yet safflower was also a common ingredient, particularly in the colored waters that Holī players squirted at one another (Sanford 2005, p. 102). The dried safflower petals produce two varieties of color. Initially, when they are soaked in liquid, the petals release a water-soluble yellow hue (Figure 7). The deep pinks and reds arise from submerging the petals in an alkaline solution after the yellow colorant has been entirely rinsed off. The dye bath is then neutralized with the addition of an acid and is ready for dyeing silk, cotton, or linen a range of red, orange, and pink colors (Bethe 1984, p. 71) (Figure 8). The initial color produced from the petals is rarely used in dyeing cloth because it quickly washes out, but the bright yellow was used in celebrations of Holī, where the point was not to dye cloth, but merely to give it a layer of color that could then be laundered away.

It is challenging to capture in painting the effects of these watery dyes' ephemerality. In most paintings of Holi, it is the density of the colors that overwhelms the picture plane, creating opaque shots of pigment in the midst of bodies twisting in revelry and play (Figure 9). Painters found a visual correlate for their process of art-making in the materials used in the celebration of Holī. As Debra Diamond has written of painted scenes of Holī: "For artists-whose tools of the trade are, after all, colored solutions and powders - the subject of Holī would have been a conscious meditation on the act of painting" (Diamond 2016, p. 108). The act of spraying colors also resembled the art of dyeing. One painting, made in eighteenth-century Kāngrā in Himachal Pradesh, seems to depict the particular effect of Holī's colors on white cloth, rendering naturalistically the way that the colored water moved over garments (Figure 10). The color slides down the folds of the female figure's dress. They are the colors of fruits and flowers-roses, melons, and apricots - and the pigments are variously dense and saturated on the crests of the garments' folds and then seem to dissipate as the white dress flares out at the bottom. The green 
bands around the woman's wrists complement the pink of her dress, and her palms and the tips of her fingers have been stained red. The figure stands alone, at the center of a paved garden path and she is surrounded by flowers whose vibrant colors rival those on her dress. In the background, beyond the white marble pavilion, the painter has rendered a tiny, active scene of figures playing Holi. The red pigment there is powdery and loose, unlike the liquid colors on the central figure's garments.

While the figure's dress in the painting has been colored through spontaneous play, dyers also offered their services to spray garments with color around the time of Holi. A nineteenth-century account from Nāshik (northern Maharashtra) stated that local safflower dyers, some of whom had emigrated from Mārwār in Rajasthan, were particularly busy "on the fifth day of the Holi festival (March and April), when people send their clothes to be sprinkled with red" (Campbell 1883, p. 174). Techniques for "sprinkling" clothing likely varied. Some textile dyers may have blown the dye through a straw to create a haze of color. While the makers of lahariya textiles used folding, tying, and dyeing techniques to approximate the waves of water that appeared in nature during the monsoon, the Holi dyers sought to replicate the appearance of cloth that had been doused with colored powders and dyes.

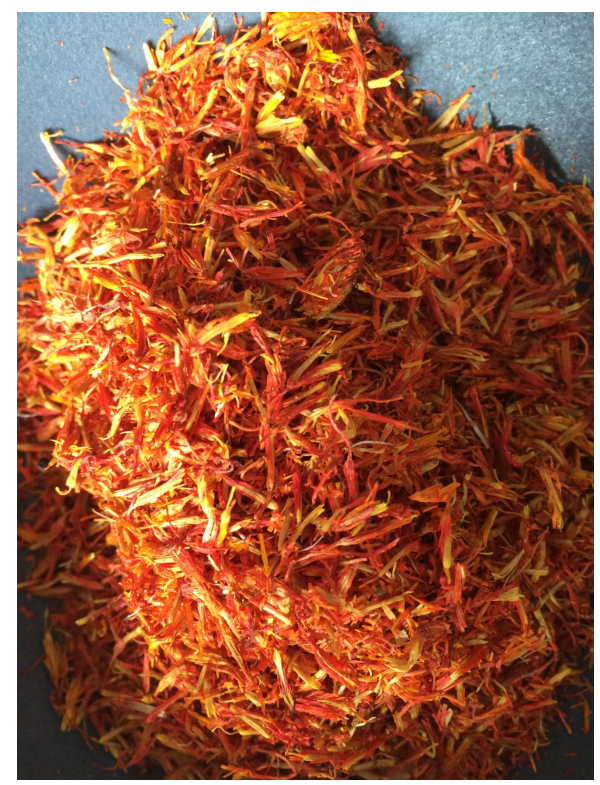

Figure 7. Safflower petals. Photograph: Sylvia Houghteling.

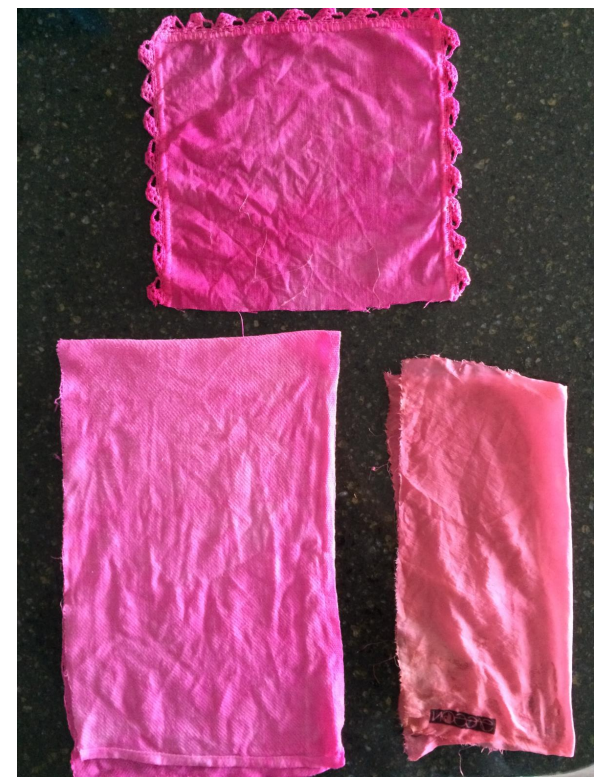

Figure 8. Cotton, linen, and silk dyed in safflower by the author. Photograph: Sylvia Houghteling. 


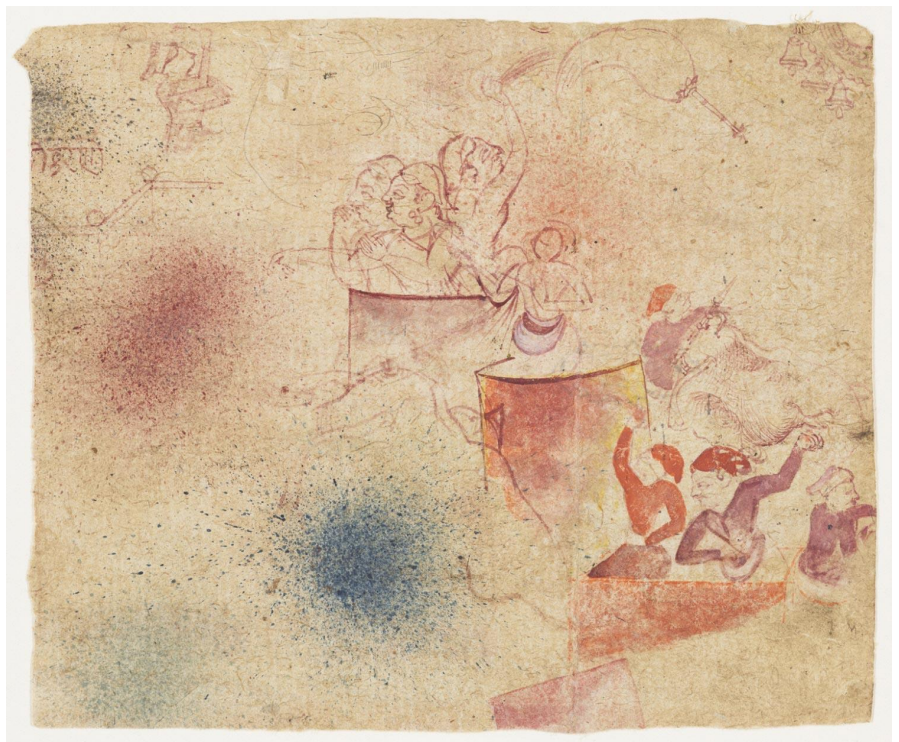

Figure 9. Artist unknown, "Noblemen on Elephant during Holi Festival”, brush and red and black inks and watercolor, brushed and spattered, on beige laid paper, Kotā, Rajasthan, India, late 18th century, Philadelphia Museum of Art: The Conley Harris and Howard Truelove Collection of Indian Drawings, 2013, 2013-77-22.

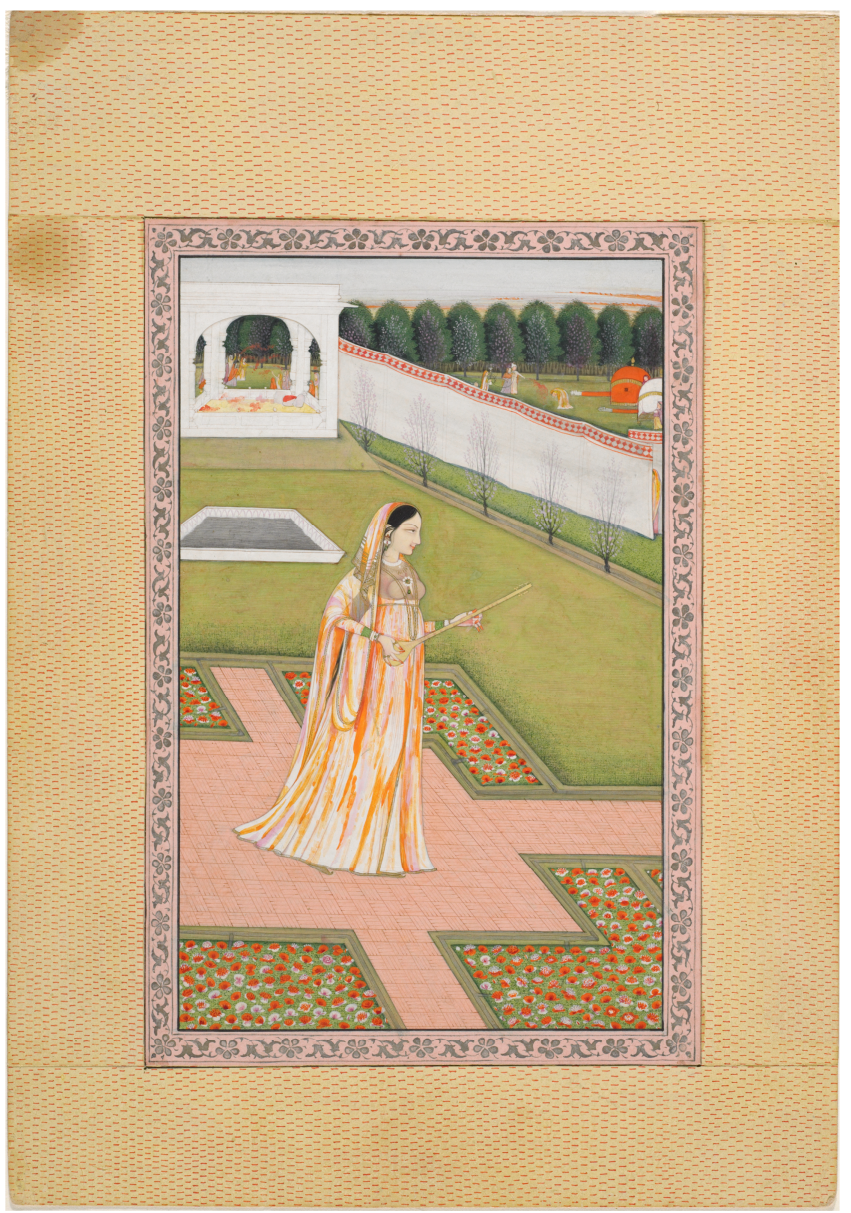

Figure 10. Unknown Artist, "Lady Alone at Holi Festival", opaque watercolor and gold on paper, Pahari School, Kangra, Himachal Pradesh, c. 1780. Harvard Art Museums/Arthur M. Sackler Museum, Gift of John Kenneth Galbraith, 1971.133. (C) President and Fellows of Harvard College. 
An echo of Holi remained even in the enduring dyes of textiles that were destined to travel long distances. The English word, "chintz", the name given to India's famous export textiles in early modern Europe, originally derived from the Hindi verb chìntna, which means to "spray" or "sprinkle" (Crill 2008, p. 9). By the end of the seventeenth century, a chint cloth had come to refer to a cotton textile that had been dyed to last. Chint cloth was made with indigo dyes, and enduring red madder or chay-root colorants that had been dyed with mordants (Figure 11). Yet in the same popular poem that described the lahariya turban, the poet connects chìnt cloth with the festival of Holi. The couplet reads: "It was the month of Phālgun, the spring season when her spouse arrived remembering their old love. He playfully sprinkled (chìntnā) colored water on me and my companions sang teasing songs" (Singh 1991, p. 180). Through language, the poet draws the cloth made with permanent dyes closer to the springtime festivities. Visually too, if one looks very carefully at even the most long-lasting chintz cloth, the movement of the liquid mordants that created the designs resemble the dripping, sprinkling effects of Holī's colors (Figures 12 and 13).

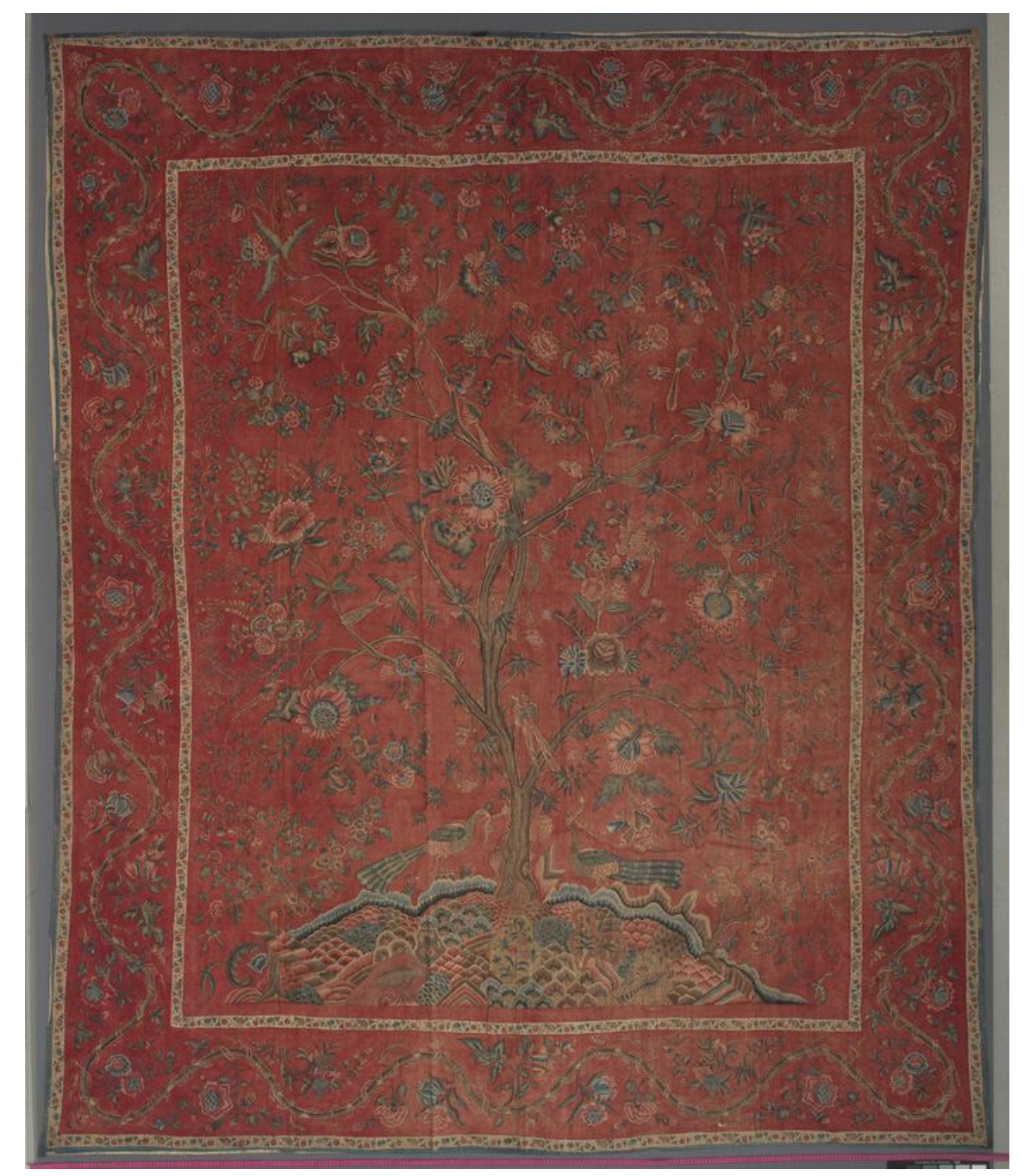

Figure 11. Palampore (textile panel), Chintz: cotton tabby, painted, mordant-dyed, resist-dyed, overpainted, made in coastal southeast India, for the Western, possibly Dutch, market, c. 1750. Gift of Louise Hawley Stone Charitable Trust, Royal Ontario Museum (2011.27.1). Courtesy of the Royal Ontario Museum, (C) ROM. 


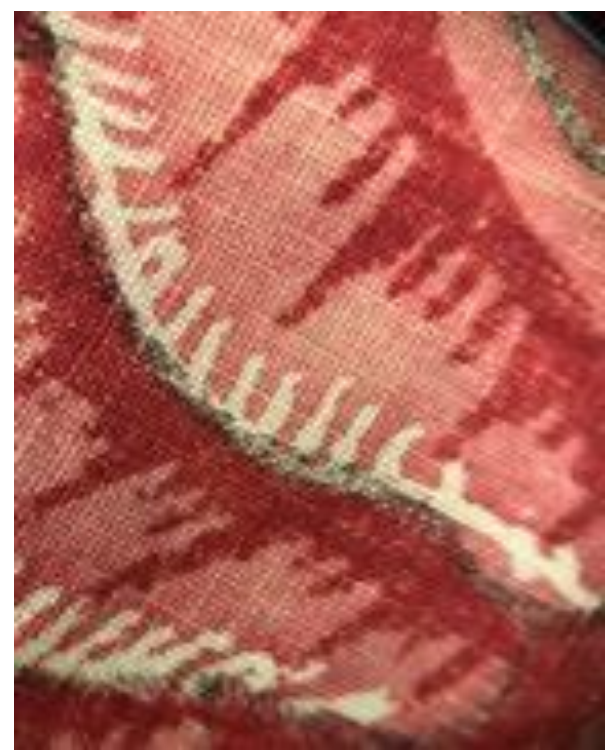

Figure 12. Detail of Figure 11, Courtesy of the Royal Ontario Museum, (c) ROM. Photograph: Sylvia Houghteling.

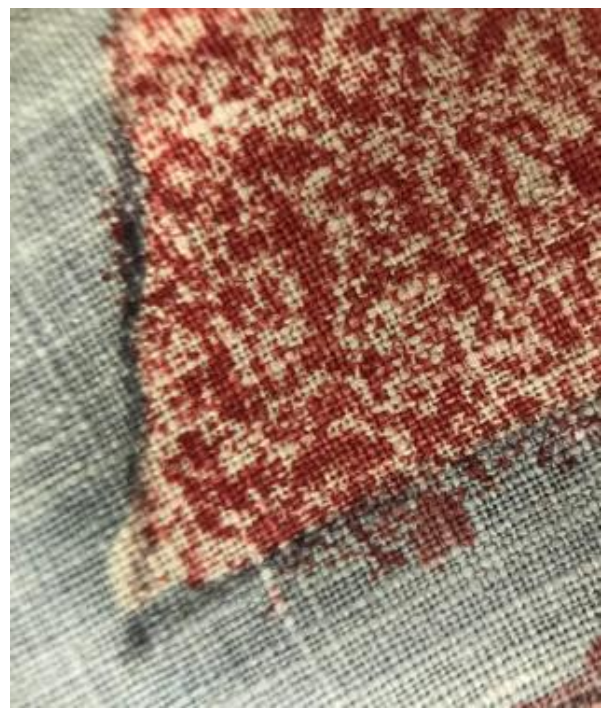

Figure 13. Detail of curtain from a set of bed hangings in the style of Jean Bérain; Chintz, cotton tabby, painted, mordant-dyed, resist-dyed, painted details, glazed, made in coastal southeast India for the Western market, 1720-1740, Harry Wearne Collection, Gift of Mrs. Harry Wearne, Royal Ontario Museum (934.4.15 A). Courtesy of the Royal Ontario Museum, (C) ROM. Photograph: Sylvia Houghteling.

\section{Conclusions}

Dyes enlivened medieval and early modern gift-giving, and brought color and drama to monsoon and springtime festivals. They also lent to literature a metaphor for an in-between temporality, allowing religious feelings or loving sentiments to be deeply felt, but also quickly spread or passed over. As the chint couplet suggests, however, it is also poetry that helps us to recognize the value in sprinkled, spreading, running dyes. With the rise of the long-distance trade in textiles, the stability and duration of dyes became one of the most significant determinants of value on the global market. The poets of cloth would disagree with this valuation, recognizing that like the fruits and flowers for which they were named, dyes were at their most potent when they transformed a mood or incited desire, even if they quickly faded away. As Amīr Khusrau wrote, a strong springtime dye of devotion merited mortgaging his youthful bloom. 
Funding: This research received no external funding.

Acknowledgments: The author appreciatively acknowledges the generous feedback from audiences at The Metropolitan Museum of Art Fellows Colloquium, the Bryn Mawr College Center for Visual Culture, the University of Wisconsin-Madison, the Johns Hopkins University Department of the History of Art, the Renaissance Society of America, and the Victoria and Albert Museum. Many thanks to Phyllis Granoff and Sonya Rhie Mace, Sussan Babaie, Ruth Barnes, Rebecca Brown, Sheila Canby, Rosemary Crill, Pika Ghosh, Christiane Hille, Parviz Holakooei, Anna Jackson, Theresa Kelley, Dipti Khera, Lavanya Mani, Ünver Rüstem, Vera-Simone Schulz, Holly Shaffer, Ursula Sims-Williams, Nobuko Shibayama, Chandramani Singh, Susan Stronge, and Benjamin Zucker.

Conflicts of Interest: The author declares no conflict of interest.

\section{References}

Ali, Daud. 2004. Courtly Culture and Political Life in Early Medieval India. Cambridge: Cambridge University Press. Ali, Daud. 2011. Rethinking the History of the Kāma World in Early India. Journal of Indian Philosophy 39: 1-13.

Ali, Daud. 2016. Bhoja's Mechanical Garden: Translating Wonder across the Indian Ocean, Circa 800-1100 CE. History of Religions 55: 460-93.

Apte, Vaman Shivaram. 1959. Revised and enlarged edition of Prin. V. S. Apte's The Practical Sanskrit-English Dictionary. 3 vols. Poona: Prasad Prakashan. First published 1957.

Bailkin, Jordanna. 2005. Indian Yellow: Making and Breaking the Imperial Palette. Journal of Material Culture 10: 197-214.

Bethe, Monica. 1992. Reflections on Beni: Red as a Key to Edo-Period Fashion. In When Art Became Fashion: Kosode in Edo-Period Japan. Edited by Dale Carolyn Gluckman and Sharon Sadako Takeda. Los Angeles: Los Angeles County Museum of Art, pp. 133-53.

Barnes, Ruth. 1997. Indian Block-Printed Textiles in Egypt: The Newberry Collection in the Ashmolean Museum, Oxford. Oxford: Oxford University Press.

Bethe, Monica. 1984. Color: Dyes and Pigments. In Kosode: 16th-19th Century Textiles from the Nomura Collection. Edited by Amanda Mayer Stinchecum. New York: Japan Society and Kodansha International, pp. 58-77.

Bhandari, Vandana. 2004. Costume, Textiles and Jewellery of India: Traditions of Rajasthan. New Delhi: Prakash Books India.

Brick, David. 2009. The Dānakāṇụa ("Book on Gifting") of the Kṛtyakalpataru: A Critical Edition and Annotated Translation. Ph.D. dissertation, University of Texas, Austin, TX, USA.

Brown, Rebecca. 2020. The Gold, the Gold; the Glory, the Glory: Overcome by Colour in the 1870s and the 1980s. Third Text Forum Online. Available online: http://www.thirdtext.org/brown-thegold (accessed on 12 March 2020).

Campbell, James MacNabb. 1883. Gazetteer of the Bombay Presidency: Násik. Bombay: Government Central Press, vol. XVI.

Chandra, Moti. 1973. Costumes, Textiles, Cosmetics \& Coiffure in Ancient and Medieval India. Delhi: Oriental Publishers.

Cohen, Steven. 2015. Materials and Making. In The Fabric of India. Edited by Rosemary Crill. London: V\&A Publishing, pp. 16-77.

Crill, Rosemary. 2008. Chintz: Indian Textiles for the West. London: V\&A Publications.

Dale, Stephen F. 2009. Silk Road, Cotton Road or ... Indo Chinese Trade in Pre-European Times. Modern Asian Studies 43: 79-88.

Diamond, Debra. 2016. Holi in the Zenana: Genre, Style and Sociability. In A Magic World: New Visions of Indian Painting. Edited by Molly Emma Aitken. Mumbai: Marg, pp. 99-115.

Eaton, Natasha. 2012. Nomadism of Colour: Painting, Technology and Waste in the Chromo-zones of Colonial India c.1765-c.1860. Journal of Material Culture 17: 61-81.

Eaton, Natasha. 2013. Colour, Art and Empire: Visual Culture and the Nomadism of Representation. London: I. B. Tauris.

Ethé, Hermann. 1903. Catalogue of Persian Manuscripts in the Library of the India Office. Oxford: Printed for the India Office.

Fee, Sarah, ed. 2020. The Cloth that Changed the World: The Art and Fashion of Indian Chintz. New Haven: Yale University Press, Toronto: Royal Ontario Museum.

Flatt, Emma. 2019. The Courts of the Deccan Sultanates: Living Well in the Persian Cosmopolis. Cambridge: Cambridge University Press. 
Gittinger, Mattiebelle. 1982. Master Dyers to the World: Technique and Trade in Early Indian Dyed Cotton Textiles. Washington, DC: Textile Museum.

Graham, Jayne. 2009. Waves of Colour: Lahariya Turbans of Rajasthan. Hali 160: 62-65.

Granoff, Phyllis. 2004. Luxury Goods and Intellectual History: The Case of Printed and Woven Multicolored Textiles in Medieval India. Ars Orientalis 34: 151-71.

Granoff, Phyllis. 2020. Coloring the World: Some Thoughts from Jain and Buddhist Narratives. Religions 11: 9. [CrossRef]

Hofenk de Graaff, Judith H. 2004. The Colourful Past: Origins, Chemistry and Identification of Natural Dyestuffs. Riggisberg: Abegg-Stiftung, London: Archetype Publications.

Huet, Pierre-Daniel. 1719. Memoirs of the Dutch Trade in All the States, Empires, and Kingdoms in the World. London: C. Rivington.

Jackson, Anna, ed. 2020. Kimono: Kyoto to Catwalk. London: V\&A Publications.

Jain-Neubauer, Jutta, ed. 2016. Water Design: Environment and Histories. Mumbai: Marg.

Jha, Sadan. 2014. Challenges in the History of Colours: The Case of Saffron. The Indian Economic and Social History Review 51: 199-229.

Khera, Dipti. 2020. The Place of Many Moods: Udaipur's Painted Lands and India's Eighteenth Century. Princeton: Princeton University Press.

Khulāṣat al-Mujarrabāt. 1766. IO Islamic 2814. London: The British Library.

Losensky, Paul, and Sunil Sharma, trans. and eds. 2011, The Selected Poetry of Amīr Khusrau: In the Bazaar of Love. New Delhi: Penguin Books.

Lally, Jagjeet. 2019. Colour as Commodity: Colonialism and the Sensory Worlds of South Asia. Third Text Forum Online. Available online: www.thirdtext.org/lally-colourascommodity (accessed on 9 May 2019).

Marriott, McKim. 1968. Caste Rankings and Food Transactions: A Matrix Analysis. In Structure and Change in Indian Society. Edited by Milton B. Singer and Bernard S. Cohn. Chicago: Aldine Pub. Co., pp. 133-72.

Mukharji, T.N. 1883. A Hand-Book of Indian Products (Art-Manufactures and Raw Products). Calcutta: J. Patterson.

Munshi, Kalpalata K. 1959. Śrñgāramañjarī Kathā. Bombay: Bharatiya Vidya Bhavan.

Murphy, Veronica, and Rosemary Crill. 1991. Tie-Dyed Textiles of India: Tradition and Trade. New York: Rizzoli in association with the Victoria and Albert Museum.

Naqvi, Hamida Khatoon. 1980. Colour Making and Dyeing of Cotton Textiles in Medieval Hindustan. Journal of History of Science 15: 58-70.

Nieto-Galan, Agustí. 2010. Between Craft Routines and Academic Rules: Natural Dyestuffs and the "Art" of Dyeing in the Eighteenth Century. In Materials and Expertise in Early Modern Europe: Between Market and Laboratory. Edited by E.C. Spary and Ursula Klein. Chicago: University of Chicago Press, pp. 321-87.

Phipps, Elena. 2013. Global Colors: Dyes and the Dye Trade. In Interwoven Globe: The Worldwide Textile Trade. Edited by Amelia Peck. New York: Metropolitan Museum of Art, pp. 120-35.

Platts, John T. 1884. A Dictionary of Urdu, Classical Hindi, and English. London: W. H. Allen \& Co.

Pollock, Sheldon. 2016. A Rasa Reader: Classical Indian Aesthetics. New York: Columbia University Press.

Qureshi, Regula Burckhardt. 1993. Sufi Music and the Historicity of Oral Tradition. In Ethnomusicology and Modern Music History. Edited by Daniel M. Neuman, Philip Vilas Bohlman and Stephen Blum. Urbana and Chicago: University of Illinois Press, pp. 103-20.

Ray, Sugata. 2017. Hydroaesthetics in the Little Ice Age: Theology, Artistic Cultures and Environmental Transformation in Early Modern Braj, c. 1560-70. South Asia: Journal of South Asian Studies 40: 1-23.

Riello, Giorgio. 2010. Asian knowledge and the Development of Calico Printing in Europe in the Seventeenth and Eighteenth Centuries. Journal of Global History 5: 1-28.

Sanford, A. Whitney. 2005. Holī through Dhaūjī's Eyes: Alternate Views of Krishna and Balarāma in Dhaūjī. In Alternative Krishnas: Regional and Vernacular Variations on a Hindu Deity. Edited by Guy L. Beck. Albany: State University of New York Press, pp. 91-112.

Sarkar, Smritikumar. 2015. Indigo Dyeing in the Land of its Origin: History Unknown. In The Handbook of Textile Culture. Edited by Janis Jefferies, Diana Wood Conroy and Hazel Clark. London: Bloomsbury, pp. 387-400.

Shibayama, Nobuko, Mark Wypyski, and Elisa Gagliardi-Mangilli. 2015. Analysis of Natural Dyes and Metal Threads used in 16th-18th century Persian/Safavid and Indian/Mughal Velvets by HPLC-PDA and SEM-EDS to Investigate the System to Differentiate Velvets of these Two Cultures. Heritage Science 3: 1-20. 
Singh, Chandramani. 1991. Two Medieval Compositions on Indian Textiles. In Pathways to Literature, Art, and Archaeology. Edited by Chandramani Singh and Neelima Vashishtha. Jaipur: Publications Scheme, vol. II, pp. 176-84.

Wardle, Sir Thomas. 1886. Dyes and Tans. In Colonial and Indian Exhibition, 1886, Empire of India-Special Catalogue of Exhibits by the Government of India and Private Exhibitors. London: William Clowes \& Sons.

Williams, Richard David. 2018. A Theology of Feeling: The Radhavallabhi Monsoon in the Eighteenth Century. In Monsoon Feelings: A History of Emotions in the Rain. Edited by Imke Rajamani, Margrit Pernau and Katherine Butler Schofield. New Delhi: Niyogi Books, pp. 71-96.

Publisher's Note: MDPI stays neutral with regard to jurisdictional claims in published maps and institutional affiliations.

(C) 2020 by the author. Licensee MDPI, Basel, Switzerland. This article is an open access article distributed under the terms and conditions of the Creative Commons Attribution (CC BY) license (http://creativecommons.org/licenses/by/4.0/). 